\title{
Muddle over superhighway builders
}

The British government is heading for a monumental muddle in attempting to decide which monopoly should take charge of any British information superhighway there may be. Other governments should watch what happens.

WILL the British government or its successor (expected in 1996) be compelled to renationalize British Telecom, the largest communications company in Britain and the privatized successor to what was once a public monopoly? The question is not political, but technical and administrative. The British government (whichever party forms it) is heading for an impossible muddle over telecommunications. Faced with the difficulty of making sense of the patchwork it has made for itself, it may well decide that it has no choice but to start again, with a blank sheet of paper. But nobody can be sure that it would make a better job of shaping the telecommunications industry if it had a second chance.

The circumstances are these. The privatization of British Telecom was at the centre of the ambitions of the Conservative government elected 15 years ago. Soon afterwards, in the person of Mr Kenneth Baker, then minister of information technology, the government also decided to "cable Britain", dividing Britain into geographical pieces and awarding franchises to companies willing to provide cable-television services commercially. The franchises required that the operators should install cable systems that were technically advanced in 1981. The cabling of Britain has nevertheless hung fire, partly because of the tax treatment of the money spent in digging up Britain's streets. To make the packages more palatable, the cable companies have been allowed to offer telephony as well as television signals to their subscribers, but British Telecom cannot (for another two years) offer its subscribers even a pay-TV service.

Now, matters have been further complicated by the advocacy by the US vice-president, Al Gore, of the 'information superhighway'. Who would build its British equivalent? A House of Commons select committee is expected this week to report that the cost would amount to $£ 15$ billion and that the benefits would be worth much more. That is believable. But the essence of the multi-media business is that offices and houses are connected by a single broad-bank link to a network carrying a variety of signals.

The dilemma for the British government is that it will soon be forced to choose whose holes in the ground should carry the optical-fibre cables of the superhighway, British Telecom's or the cable companies'? Either choice would put the neglected competitor out of business, causing a huge rumpus. The shareholders would have to be compensated, perhaps even bought out. Requiring British Telecom to buy out the cable companies would be another solution, but one that would saddle consumers with needless costs and recre- ate a monopoly in telecommunications the present government hoped to end for good.

The moral in this tale is simple. Arranging that monopolies, whether public or private, function efficiently and deal equitably with their customers is never easy. Doing so in fields in which the technology is changing quickly is especially dangerous, and can be disastrous. In the British case, short-sighted franchising has already saddled the country with almost twice as much cabling beneath the streets as it really needs, together with an organizational structure that cannot easily be used to operate an information superhighway. Starting all over again might well be simpler.

\section{Goodbye to academia}

US grant agencies should be kinder to postdocs or reckon that the supply of young researchers will shrink.

Is research no longer attractive to the young? That is the question provoked by the surprising decline in the number of research grants to people under 37 awarded by the US National Institutes of Health (NIH). By all accounts, the absolute number of grants to people in this age-cohort fell by 54 per cent between 1985 and 1993 (see Nature 370, 87; 1994). Even if the cornucopia that is NIH may not be what it was when its budget grew much faster than inflation, it is natural that the managers are asking, "Where have all the young researchers gone?"

The managers will find parts of an explanation under their own noses, in the competitive grants system they administer. Over three decades, this system has endowed the United States with the most competitive and productive system of biomedical research the world has ever known. Principal investigators compete for grants in the knowledge that only success can ensure that they and their colleagues continue to work in an academic environment. It is a commonplace that the burden of competition falls on the shoulders of the army of postdoctoral fellows inhabiting US biomedical research laboratories; theirs are the lights routinely burning until the small hours of the morning, accumulating the data on which the next grant application will be based, or slicing a publishable paper into smaller pieces to magnify the laboratory's publications record. They are also the most vulnerable members of the team, the first to lose their jobs when a grant comes to an end or is curtailed. Rarely will a parent institution help 